\title{
DISTRIBUTIONAL PATTERNS IN BRAZILIAN SERJANIA (SAPINDACEAE)
}

\author{
Pedro Acevedo-Rodríguez ${ }^{1}$
}

RESUMO - O presente trabalho analisa a distribuição de Serjania no Brasil, através da comparação das espécies ocorrentes nas três maiores regiões fitogeográficas do país: a costa Atlântica, o planalto e a bacia Amazônica. A costa Atlântica tem o maior percentual de espécies endêmicas $(70 \%)$ e muitas das espécies da região também ocorrem no planalto. As espécies do planalto também podem ocorrer em países vizinhos, mas $33 \%$ delas são endêmicas. A bacia amazônica tem apenas $4 \%$ de espécies endêmicas e a maioria das espécies são amplamente distribuídas na área.

Palavras-chave: Serjania, Brasil, mata Atlântica, planalto, bacia Amazônica, endemismos, cerrado, floresta da galeria, campos, terra-firme, floresta, restinga.

\begin{abstract}
The present paper analyzes the distribution of Serjania in Brazil, by comparing and contrasting the species occuring in three major phytogeographic regions: the Atlantic coast, the planalto, and the Amazon basin. The Atlantic coast region has the highest percent $(70 \%)$ of species endemic to the area, and shares many species with the planalto region. The planalto region shares most of its species with the Atlantic coast and the neighboring countries, but still has a $33 \%$ of endemic species to the area. The Amazon basin has only a $4 \%$ of species endemic to the area, with most of the reminder species widely distributed throughout the area.
\end{abstract}

Key-words: Serjania, Brazil, mata Atlântica, planalto, Amazon basin, endemics, cerrado, gallery forest, campos, terra-firme, forest, restinga.

1 - Departament of Botany, National Museum of Natural History; Washington, D. C. 


\section{Introduction}

Species of Seriania are mostly perennial, woody climbers, with samaroid mericarps, native to the neotropics. Serjania is either dispersed by wind or water currents, in dry, open areas, wind is the predominant dispersal vector whereas in gallery or seasonally flooded forests water currents are the principal mode of dispersal.

Serjania has approximately 226 species, distributed from southwestern United States to northern Argentina, including the West Indies. The major center of distribution for Serjania, is in southern Mexico with 48 species. Two minor centers, containing approximately 35 species are found in Brazil, one in the central planalto, and another along the Atlantic coast.

The present state of knowledge regarding Serjania, indicates that the majority $(60 \%)$ of the species occupy a medium geographical range (i.e., a quarter to a third of the area of the continent), followed by species $(35 \%)$ which occupy a restricted range (endemic, usually known from a single or a few collections) and by species $(5 \%)$ with a wide geographical range (i.e., throughout the continent).

The great majority of Serjania species occur in thickets or in relatively open vegetations, along margins of gallery forests or in disturbed areas. Few species occur in areas above $1500 \mathrm{~m}$ elevation, and no species have been collected above $3000 \mathrm{~m}$.

Diversity patterns in Serjania are not thoroughly understood. This is shown by the fact that in the last decade there have been 11 new species described for Brazil (Ferrucci 1981, 1983; Acevedo-Rodríguez 1986, 1987; Sommer 1988). The number of known species is expected to increase as the result of explorations of understudied areas.

The distribution of Serjania contrasts with that of the closely related Paullinia because of its preference for drier and more open environments. Although there is some overlap in the distribution of the two genera, the vast majority of species of Paullinia occupy humid dense forests, especially in the amazon area. This pattern is understandable in light of the fact that the mode of dispersal in Paullinia is zoochory.

\section{Methodology}

Analysis of the distributional patterns consisted of examining all specimens of Serjania present at New York Botanical Garden and U.S. National Herbarium, plus some selected specimens of other major herbaria in United States and Europe. This analysis relies on the species concept as interpreted by Radlkofer (1931) in Das Pflanzenreich, and on the specimens cited therein.

In order to study the distributional pattern of Serjania, it is convenient 
to contrast the number of Serjania species (endemics and non-endemics) occurring in the different phytogeographical regions discussed by many workers. For the purpose of this analysis I will follow the 3 major regions proposed by Rizzini (1967), the Amazon, the Central planalto and the Atlantic coastal region.

\section{Results}

Serjania in Brasil

There are approximately 92 species of Serjania occurring in Brazil, 47 of which are endemic (Figure 1; Appendix 1). Additionally there are 7 species with narrow ranges which extend from some of the Brazilian states to neighboring countries (Appendix 1). The great majority of Serjania species occur along margins of gallery forests which dissect cerrado and campo rupestre vegetations. A vast number of species occur in restinga vegetation, thickets or disturbed areas.

The ecological importance of Serjania seems to decrease from wetter to drier vegetation types. Goodland (1969) showed how the abundance of $S$. grandiflora and $S$. erecta decreases with decreasing tree densities along a declining moisture gradient, i.e., there are fewer species of Serjania in the continuum from cerradão-cerrado-campo cerrado to campo sujo.

\section{The Atlantic Coast}

The Atlantic coast contains approximately 35 species of Serjania, 25 of which are endemic to the region (Figure 2; Appendix 2). The dispersion of the endemic species in this area varies from very localized and rare, to widely distributed and common. Serjania bahiana, $S$. faveolata, $S$. magnistipulata, $S$. morii, $S$. oxytoma, $S$. subimpunctata from Bahia (BA), and $S$. acuminata, $S$. fluminensis, $S$. hamuligera, $S$. macrostachya, $S$. serrata and $S$. truncata from Rio de Janeiro (RJ), for example are only known from the type or from a few collections. Other species such as $S$. cuspidata, $S$. dentata, $S$. elegans, $S$. ichthyoctona, and $S$. scopulifera are relatively common throughout the region. A large number of species are found in the restinga, in mata de restinga, or in disturbed areas, and a few species are found in the Atlantic forest (Mata Atlântica).

The Atlantic region shares many species with the planalto region, a few with the Amazon, and a single species with tropical America.

The greatest number of endemics, are present in the state of Bahia with 17 species, 10 of which are shared with other states. Bahia has a greater affinity 
with the state of Rio de Janeiro, with six endemics in common, it also shares four with Minas Gerais (MG) and three with Pernambuco (PE). Most of the species either occur in the restinga or in the Mata Atlântica. The state of Rio de Janeiro is second to Bahia with 13 endemics, 6 of which are shared with other states, especially with Bahia, but also with the coastal states of Ceará (CE), Espírito Santo (ES), Pernambuco and São Paulo(SP). São Paulo has 9 endemic species, 7 of which are present in other states. It shares most of the endemics with Minas Gerais, but also shares some with the southeastern states of Bahia, Rio de Janeiro, and Santa Catarina (SC). The states of Pernambuco and Espírito Santo have 3 endemics, all of which are shared with Bahia and Rio de Janeiro. Ceará, Paraná (PR), and Santa Catarina have only one endemic species of Serjania which is shared with other states.

The number of endemic species of Serjania decreases to the north and to the south of Bahia along the Atlantic fringe.

\section{The planalto region}

The planalto region contains approximately 36 species of Serjania 11 of which are endemic to the region (Figure 3; Appendix 1). Most of these endemic species seem to have a restricted distribution, however, this pattern might be the result of collecting artifact as most of them are known from one or from a few collections. For instance, $S$. fusca, $S$. lamelligera, $S$. laxiflora, $S$. paleata, $S$. purpurascens, $S$. setigera, $S$. suborbicularis, $S$. trichomisca and $S$. tricostata are known from a few collections beyond the type. Serjania orbicularis and $S$. paludosa although not very common, are known from many collections.

In addition to the strictly endemic species of the central region, there are six Brazilian endemics found in the Atlantic coast and the central planalto regions. There are also six species with restricted distribution, occurring in the the central planalto region but extending to Bolivia, Paraguay and northern Argentina.

Most of the Serjania species (including the non-endemic ones) occurring in the central region also occur along the Atlantic coast, and the neighboring countries of Paraguay and northern Argentina. There are a few species which also occur in the Peruvian and Bolivian Amazon, and throughout tropical America.

The great majority of species occurring in the planalto are found along gallery forests and in campos vegetation.

The state of Minas Gerais has the greatest number of endemics in this region with 13 species, 7 of which are shared with other states. Minas Gerais has four endemics in common with Bahia, and three endemic species of Serjania with São Paulo and Goiás (GO). The state of Minas also shares one endemic with Mato Grosso (MT) and with Mato Grosso do Sul (MS). 
The state of Goiás has five endemic, four of which are shared with other states. Goiás has greater affinity with Minas Gerais, sharing 3 species with it.

Mato Grosso has three endemics, of which 2 are shared with Minas Gerais and São Paulo.

\section{The Amazon Basin}

The Amazon region has approximately 26 species of Serjania, with one species endemic to the states of Amazonas and Pará. Additionally there are two species which extend to the Amazon region of Colombia, Ecuador and Peru. (Figure 4; Appendix 4). Most of the species occurring in this zone have a wide distribution, being found throughout the Amazon region in Ecuador, Peru and Bolivia. Many species are also found in northern South America, and a few along the Atlantic coast of Brazil, or distributed throughout tropical America.

Many of the species in the Amazon region occur in disturbed areas such as roadsides and terra firme forest gaps. The lowest number of endemic species for the genus in Brazil occur in the amazon region. Serjania exarata is the only species strictly endemic to the region, however, this notion may change if it shown to be conspecific with $S$. membranacea. Serjania inscripta and $S$. trirostris are both found in the state of Amazonas, but their ranges extend to Peru.

The states of Amazonas (AM) and Pará (PA) have the only species of Serjania strictly endemic to the region.

\section{Discussion}

Species of Serjania occurring in wet areas seem to have a wider distribution than those ocurring in open or drier areas. This pattern might be due to the fact that water currents play a major role in dispersing Serjania propagules in wetter areas. Its wide distribution could be a result of the prolific number of rivers dissecting the Amazon region, and ultimately to the adaptation of these species to wetter regimes.

At this point, it is not clear whether distributional patterns in open and dry areas are due to physical barriers or to ecological specialization. The fact that Serjania species in this zone occur in a vast number of ecosystems, may suggest the presence of niche specialization, however, this needs to be confirmed by field work. Another striking possibility is the fact that Serjania has highly variable mericarps (size, shape and proportional wing size), which might account for differential dispersability, resulting in different distributional patterns.

A contrast between the central planalto region and the Atlantic coast show different dispersion patterns, which might be due an artifact of the collection process. In any case, this point to the necessity for increasing the number of collections for the area. 
Appendix 1: Endemic species of Serjania from Brazil

S. tenuis (1) RJ

S. regnelli (2) MG, SP

S. cuspidata (3) BA, RJ, SP

S. trichomisca (4) GO

S. paludosa (5) MG

S. inscripta (6) AM; Peru

S. setigera (7) MS

S. platycarpa (8) GO, MS, SP

S. eucardia (9) BA, CE, PE, RJ

S. subimpunctata (10) BA

S. paleata (11) MG

S. laxiflora (12) MG

S. dentata (13) BA, ES, RJ

S. lamprophylla (14) MG, SP

S. faveolata (15) BA

S. thoracoides (16) ?

S. pinnatifolia (17) BA, GO, MG

S. ichthyoctona (18) RJ, BA

S. lamelligera (19) MG

S. oxytoma (20) BA

S. grammatophora (21) BA

S. pernaumbusensis (22) BA, PE

S. serrata (23) RJ

S. cissoides (24) MS; Paraguay

S. chaetocarpa (25) MG, MS, MT, Paraguay

S. purpurascens (26) MG

S. paradoxa (27) BA, MG, SP

S. hamuligera (28) RJ

S. acuminata (29) RJ

S. crassifolia (30) GO: Bolivia

S. dura (31) SP

S. fluminensis (32) RJ

S. orbicularis (33) GO, MG, MT

S. perulacea (34 GO, MG, Ms, Argentina; Paraguay

S. punctulata (35) PR

S. salzmanniana (36) BA, PE

S. velutina (37) GO

S. unidentata (38) SC, SP

S. tristis (39) MG, SP

S. bahiana (40) BA

S. hatschbachii (41) SP

S. magnistipulata (42) BA

S. morii (43) BA

S. circumvallata (44) AM; Colombia

S. exarata (45) AM, PA

S. trirostris (46) AM; Peru

S. decemstriata (47)?

S. fusca (48) MT

S. macrostachya (49) RJ restinga

campos

restinga

gallery forest

swamp

terra firme and várzea forest

campos

gallery forest

restinga

forest

gallery forest

restinga

gallery forest

atlantic forest

gallery forest

restinga

seas. forest

restinga?

gallery forest

caatinga

cerrado

cerrado

gallery forest

campo

cerrado, gallery forest

restinga

campos

campos

forest

restinga

gallery forest

secondary forest

gallery forest

caatinga

forest

atlantic forest

atlantic forest

terra firme forest

várzea forest

campos? 
S. scopulifera (50) BA, ES, RJ

S. suborbicularis (51) MG

S. tricostata (52) MT

S. truncata (53) RJ

S. elegans (54) BA, ES, MG, RJ restinga

campos

campos, restinga

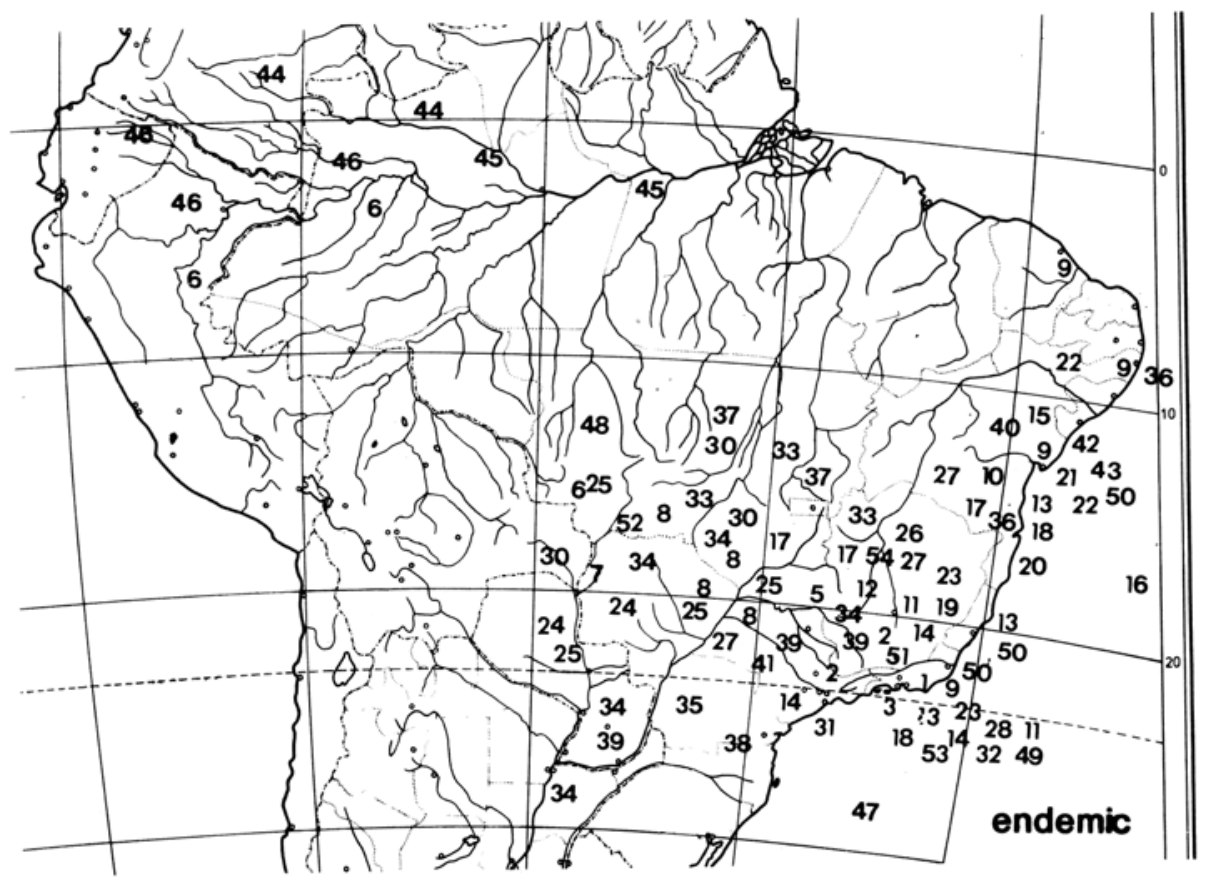

Figure 1 - Endemic species of Serjania from Brazil (see appendix 1 for legend) 
Appendix 2. Serjania spp. distributed along the Atlantic Coast

S. acutidentata (1)

S. acoma (2)

S. hatschbachii (3)

S. reticulata (4)

S. erecta (6)

S. caracasana (5)

S. multiflora (7)

S. laruotteana (8)

S. noxia (9)

S. paradoxa (10)

S. fuscifolia (11)

S. clematidifolia (12)

S. dentata (13)

S. corrugata (14)

S. gracilis (16)

S. meridionalis (17)

S. piscatoria (18)

S. eucardia (19)

S. ichthyoctona (20)

S. hebecarpa (21)

S. comata (22)

S. deflexa (24)

S. scopulifera (25)

S. lamprophylla (26)

S. communis ()

S. unidentata

S. macrostipulata

S. morii

S. punctulata

S. cuspidata ( )

S. fluminensis

S. tenuis
AM, BA, MG

PR, GO, MG, MT, SC, SP; Paraguay

SP

GO, MG, MS, PR, SP, RJ; Argentina, Bolivia

PR, BA, GO, MG, MS, MT, SP

BA, ES, GO, MG, MT, PA, RJ, SP; Tropical America

GO, MG, MS, PR, RS, SC, SP

BA, MG, PR, RS, RJ, SP; Argentina, Paraguay

MG, RJ, SP

BA, MG, SP

AM, BA, MG, RJ, SP; Argentina; Paraguay; Peru

BA, ES, MT, PA, PR, RJ, RS, SC

BA, ES, RJ

BA, ES, MG, RT

BA, GO, MG, PR, SC, SP

GO, MS, MT, PR, RS, SC, SP; Argentina; Bolívia; Uruguay

BA, GO, PR, RJ, SP

BA, CE, PE, RJ

BA, ES, RJ

BA, CE, GO, MG, MT, PE, RJ, RS; Argentina; Bolívia;

Paraguay; Uruguay

BA, GO, MG, MT, RJ; Argentina; Bolívia; Paraguay

MG, RJ

BA, RJ

MG, SP

AM, ES, GO, MG, PR, RJ, SP; Bolivia; Colombia; Ecuador;

Peru; Paraguay; Venezuela

SC, SP

BA

BA

PR

BA, SP, RJ

$\mathrm{RJ}$

RJ 


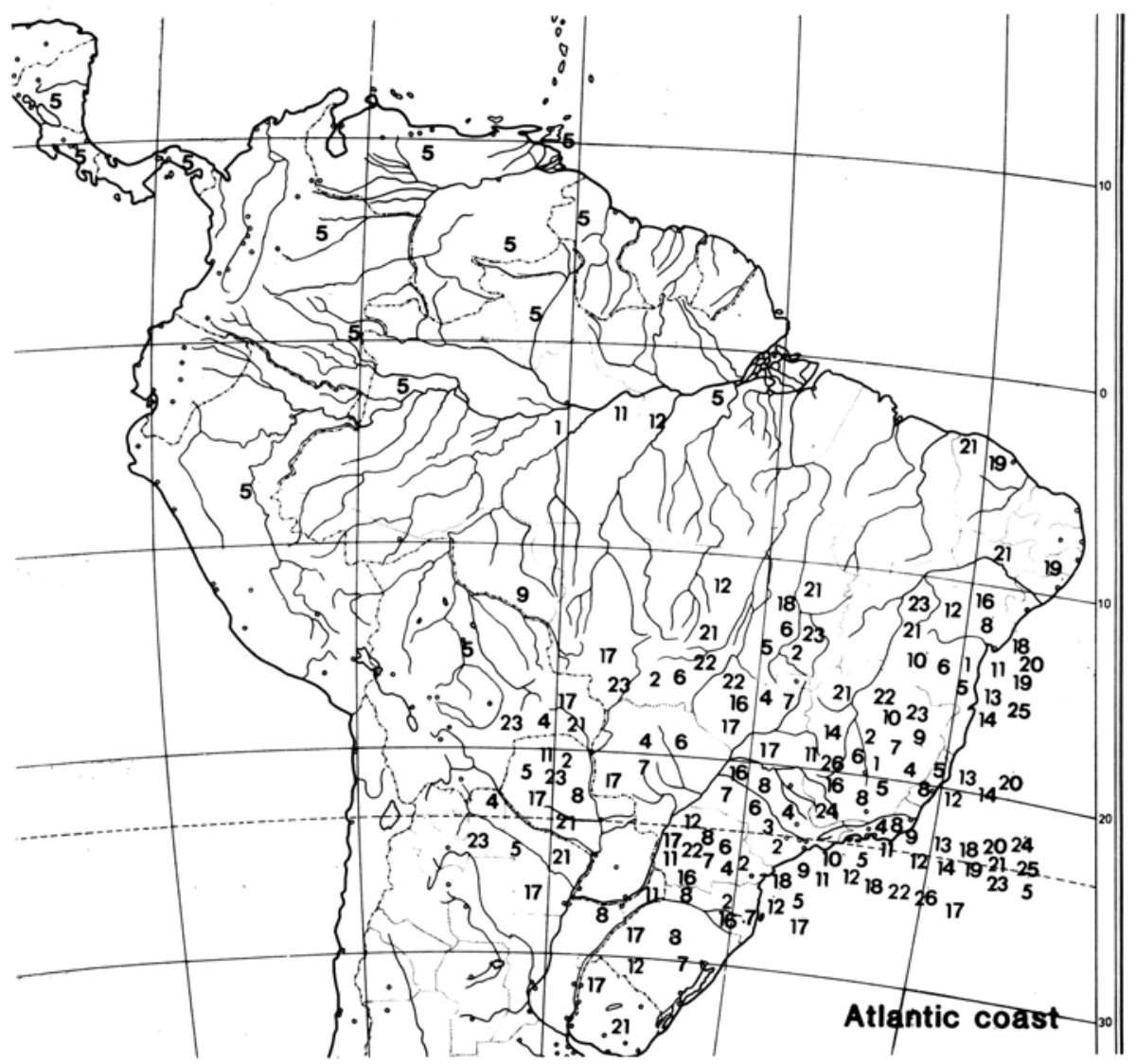

Figure 2 - Serjania spp. distributed along the Atlantic Coast (see appendix 2 for legend) 
Appendix 3. Serjania spp. occurring in planalto.

S. acutidentata (1)

S. comata (2)

S. chaetocarpa (3)

S. erecta (4) PR,

S. fuscifolia (5)

S. platycarpa (6)

S. reticulata (7)

S. hebecarpa (8)

S. lethalis (9)

S. paucidentata (10)

S. glutinosa (11)

S. ovalifolia (12)

S. crassifolia (13)

S. perulacea (14)

S. gracilis (16)

S. caracasana (17)

S. acoma (18)

S. marginata (19)

S. meridionalis (20)

S. orbicularis (21)

S. chaetocarpa (22)

S. cissoides (23)

S. glabrata (24)

S. tristis (25)

S. laxiflora

S. multiflora

S. obtusidentata $(+)$

S. pinnatifolia $(\star)$

S. pinnatifolia (+)

S. purpurascens

S. pyramidata $(\bullet)$

S. regnelli

S. tricomisca

S. velutina

S. elegans
AM, BA, MG

GO, MG, MT, PR, SP

MG, MS, MT, Paraguay

BA, GO, MG, MS, MT, SP

BA, MG, PA, PR, SP, RJ

GO, MG, MT

GO, MG, MS, PR, RJ, SP; Argentina; Bolivia

BA, CE, GO, MG, MT, PE, RS, SP; Argentina; Bolivia;

Paraguay; Uruguay

AM, BA, CE, GO, MG, MT, PE, PI, PR, RJ, SC, SP; Bolivia, Peru

AP, GO, MG, MT, PA, RD; Bolivia, Colombia, Guianas, Peru; Venezuela; Trinidad;

GO, MG, MS, MT, SP; Argentina, Paraguay

GO, PI, MG, MT, SP

GO, MT; Bolivia

GO, MG, MS; Argentina; Paraguay

BA, GO, MG, PR, SC, SP

widely sepread

GO, MG, MT, PR, SC, SP; Paraguay

BA, GO, MG, MT, RJ

GO, MG, MS, MT, PR, RS, SC, SP; Argentina, Bolivia; Uruguay

GO, MG, MT

MG, mS, MT; Paraguay

MS; Paraguay

BA, MS, PR, SC, RD; Argentina; Colombia; Ecuador; Peru;

Venezuela; Trinidad

MG, SP; Paraguay

MG

GO, MG, MS, PR, RS, SC, SP

GO, MG, MT, RD

GO, MG, MT, RD

BA, GO, MG

MG

AP, MG, PA; Bolivia; Peru;

Colombia

MG, SP

GO

GO, MT

MG 


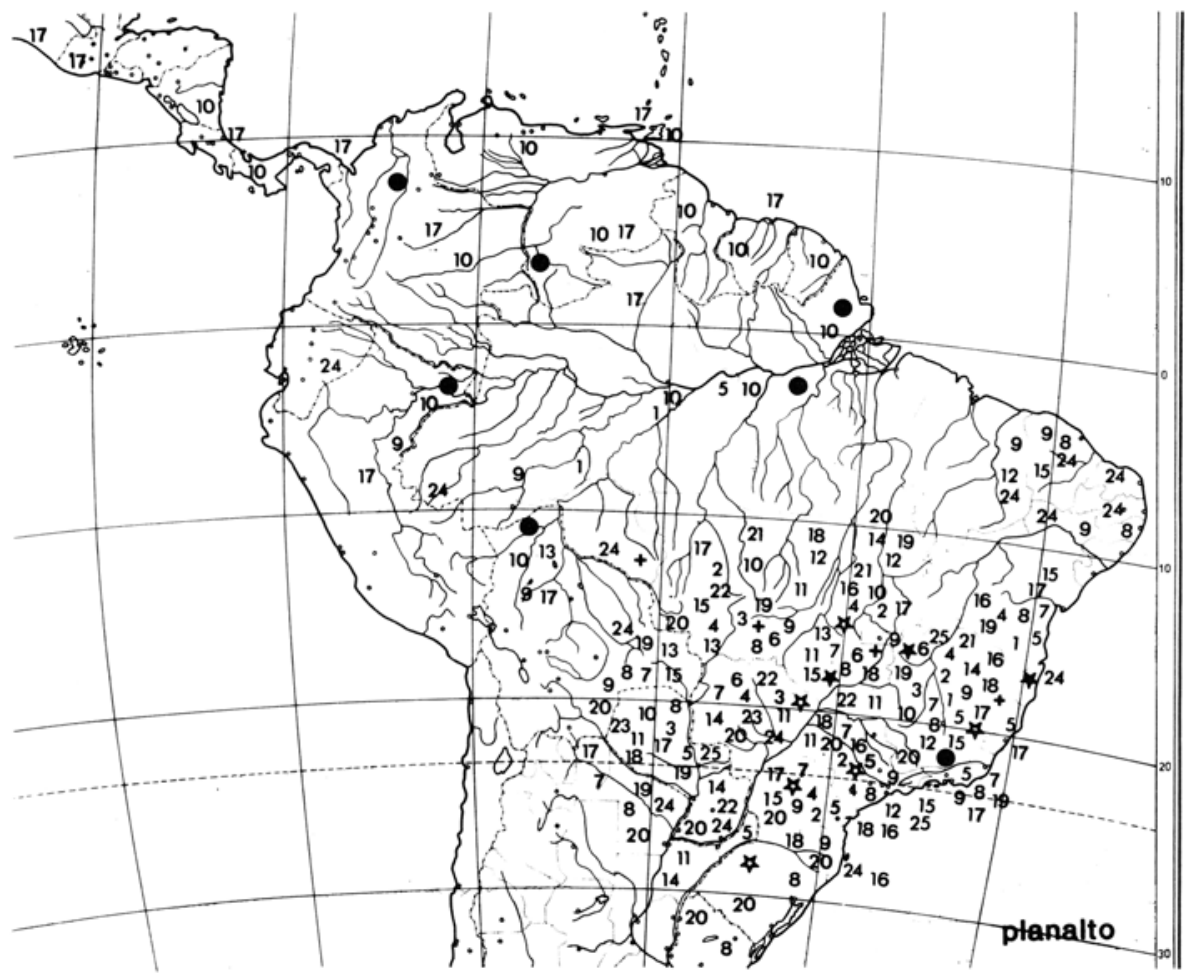

Figure 3 - Serjania species occurring in planalto (see appendix 3 for legend) 
Appendix 4. Serjania spp. occurring in the Amazon Basin.

S. elongata (1)

S. pyramidata (2)

S. grandifolia (3)

S. nigricans (4)

S. paucidentata (5)

S. membranacea (6)

S. fuscifolia (7)

S. purpurascens (8)

S. trirostris (9)

S. tenuifolia (10)

S. lethalis (11)

S. reticulata (12)

S. caracasana (13)

S. glabrata (14)

S. oblongifolia (15)

S. acutidentata (16)

S. rhombea (17)

S. inscripta (18)

S. communis (19)

S. circumvallata (20)

S. leptocarpa (21)

S. clematidea (22)

S. clematidifolia (23)

S. nutans (24)
AC, PA; Bolivia (Pando, Yungas); Peru (Huayaga, Madre de

Dios, Junin)

AP, BA, MG, PA, RD; Bolivia (Beni, Pando); Colombia (Antioquia); C. Rica, F. Guiana; Panama; Peru; Venezuela

AC, AP, BA, MT, PA; F. Guiana; Peru; Surinam

AC, RD; Bolivia (Pando)

AM, AP, BA, MG, MT, PA, RD; C. America; Bolivia; Colombia; Guianas; Peru; Tobago; Venezuela

AM, MT, PA, RO; Colombia; C. Rica; Ecuador; Nicaragua; Panama; Peru; Venezuela; Surinam

AM, MG, RJ, SP; Argentina; Paraguay; Peru

AM, MG

AM; Ecuador; Peru

AM, PA; Bolivia; Peru

AM, AP, BA, CE, GO, MG, MT, PR, RJ, SC, SP; Bolivia; Peru

AM, AP, GO, MG, MT; Bolivia

BA, ES, GO, MG, MT, PA, RJ, SP; Bolivia; C. America; Colombia; Guyana; Paraguay; Peru; Venezuela

CE, PB, SC; Argentina; Bolivia

AP; Guyana; Surinam; Venezuela

AM, BA, MG

PA; C. America; Colombia; Ecuador; Venezuela

AM; Peru

AM, ES, GO, MG, PR, RJ, SP; Bolivia; Colombia; Ecuador;

Peru; Paraguay; Venezuela

AM; Colombia

AM; Bolivia; Colombia; Ecuador; Peru; Venezuela

AM; Colombia

BA, ES, MT, PA, PR, RS, RJ, SC

AM; Bolivia; Peru 


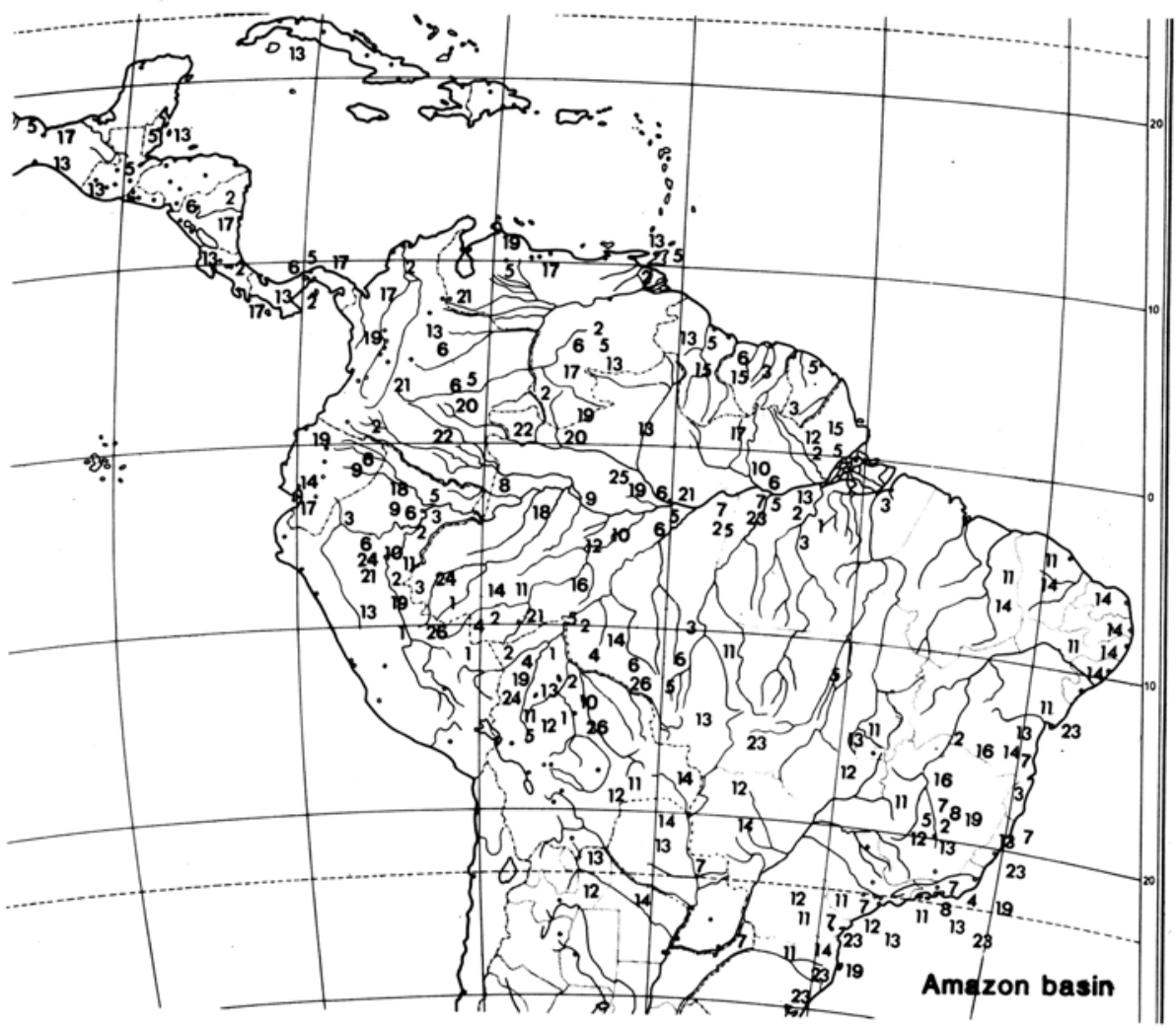

Figure $4-$ Species of Serjania occurring in the Amazon Basin (see appendix 4 for legend) 


\section{Bibliographic references}

ACEVEDO RODRIGUEZ, P. 1987. Two new species of Serjania (Sapindaceae) from Brazil. Brittonia 39: 348-352.

ACEVEDO RODRIGUEZ, P. 1988. Novelties in Serjania (Sapindaceae). Brittonia 40: 283-289.

FERRUCCI, M. S. 1981. Novedades en Houssayanthus and Serjania (Sapindaceae). Bonplandia 5(19): 169.

FERRUCCI, M. S. 1983. Novedades en Serjania (Sapindaceae). Bonplandia 5(26): 73-81.

GOODLAND, R. 1969. An ecological study of the cerrado vegetation of south central Brazil. Ph.D. thesis, Botany Dept. McGill University, Montreal. 224 p.

RADLKOFER, L. 1931. Serjania. In: ENGLER, A. (ed.). Das Pflanzenreich IV. 165 (Heft 98a-h). p. 19-219. Verlag von Wilhelm Engelmann, Leipzig.

RIZZINI, C. T. 1963. Nota prévia sobre a divisão fitogeográfica do Brasil. R. J. Instituto Brasileiro de Geografia e Estatística. Conselho Nacional de Geografia.

SOMMER, G. V. 1988. Três espécies novas de Serjania (Sapindaceae) para o estado do Rio de Janeiro. Bradea 5: 63-68.

SOMMER, G. V. 1988. Novas taxas para o gênero Serjania Miller (Sapindaceae). Bradea 5: 69-72. 